\title{
THE HISTORY OF GEOGRAPHICAL RESEARCH BETWEEN HISTORICAL BUCOVINA AND THE EXTRABUCOVINEAN TERRITORY FROM SUCEAVA COUNTY
}

\author{
DOI: https://doi.org/10.18509/AGB.2021.07 \\ UDC: 913:94(438) \\ 911.7(498:477)
}

Vasile Efros, Ciubotaru Cristian, Diacon Liliana Daniela,

Ștefan cel Mare University of Suceava, Faculty of History and Geography, Departament of Geography, Romania

corresponding author: cris_ciubotaru@yahoo.com

submitted: 17.04 .2020

accepted: 30.06 .2020

published: 10.10 .2020

\begin{abstract}
Observing, measuring and explaining discontinuities and spatial contrasts is at the heart of the geographical analysis. In the particular situation of the paper elements of physical geography enter into a less detailed analysis due to the importance of the contrasts of the humanized space. Geographical similarities with other regions of the Globe: AlsaceLorraine, South Tyrol Italy and the Transnistrian region of the Republic of Moldova At the national level, there are regions that have undergone transformations similar to Bucovina, creating contrasts of the humanized space with the neighboring areas: Banat region and Maramureș Country'. The most important bibliographic resources include three dimensions of the analysis of the geographical contrasts between the historical Bucovina and the extrabucovinean territory of Suceava county: 1. The territorial dimension; 2. The temporal evolution of geographical contrasts; 3. Geodemographic dynamics; 4. Economic contrasts; 5. Elements of ethnography; The research methodology is developed in three coordinates: 1. Bibliographic analysis; 2. Generalization of geographical elements; 3 . Comparison. Objectives of the paper: definition of the term of geographical contrast; identifying the geographical similarities with other regions of the Globe; analysis of research at national and local level.
\end{abstract}

Keywords: Bucowina, geographical contrast, analysis, Suceava

\section{INTRODUCTION}

The geographical contrasts can be divided by the natural and socio-economic order between two neighboring territories, after which they can move to a certain historical situation that determines the change of the humanized geographical landscape. The contrasts come from various factors: the historical heritage, administrative, potential differences in development, in particular, the quantity and the quality of natural and human resources. Territorial and ethno-cultural diversity can also be a valuable element that must be preserved and fructified by the introduction into

\section{MATERIALS AND METHODS}

The history of the research of geographical contrasts is achieved by the use of bibliographic sources that mention the territorial differences. The lack of concrete scientific work addressing this theme indicates a rigorous selection of the material identified by the choice of those pasages addressing a dual territorial analysis. tourist programs. At the global level, there are geographical areas similar to Bucovina in terms of evolution in other sphere of influence and the income at the territorial entity "mother". Geodemographic and economic mutations had various amplitudes determined by temporal aspects in the field of domination and administrative decisions.

In the particular situation of the work, the elements of physical geography enter in a less detailed analysis because of the importance of the contrasts of the humanized space.

Bibliographic method is the esential support of research because to the particularity of investigate theme. Generalization is a useful method, identifyng territories at national and global level, similar to the area of research. Comparison is used near the analytical approach of two geographical spaces with common identities in the work 
historical Bucowina and extrabucowinean territory of Suceava town by confronting geodemofraphic an

\section{HISTORY OF GLOBAL RESEARCH GEOGRAPHICAL SIMILARITIES WITH OTHER REGIONS ON THE GOBE}

Alsace-Lorraine, France, in the east of France, on the border with Germany, constitues similarities by annexation, changing demographic characteristics and reforming the economy through the succession of French and German domination.

Paul Vidal de la Blace's book, „La France de l'Est" (Lorraine-Alsace) ", from 1916, has a content that addresses aspects of economic geography and of population. It proves the geographical similarities with France and the geodemographic contrasts with Germany, promotes multiculturalism and eliminates racial supremacy. [1]

William Oualid in ,L'évolution industrielle de 1 'Alsace-Lorraine et de France from 1914 untill 1921", from 1921, offers an x-ray of the industrial evolution of German-dominated territory compared to other departments in France. The comparatively welded branches are the extractive and metallurgical industry, also analyzing the upward evolution of the industrial production. The employed population by sectors of activity and the evolution of time are taken into account. [2]

South Tyrol, Italy. Geodemographic equivalence with Bucovina is marked by ethno-linguistic diversity, contrast with other regions regarding architecture, customs, gastronomy. "Wood civilization" is present in various fields of activity. Jens Woelk analyzes the South Tyrol with the help of geographical observation and historical background in the work ,South Tyrol is (not) Italy: A Special Case in a (De) federalizing system". With the crossing of the border, he finds a spatial synonym with Austria, specifying the differences with the other regions of Italy. He analyzes the national and European context regarding the evolution of the state of the autonomous region South Tyrol. [3]

Kager Thomas in „South Tyrol: Mitigated but not Resolved 1998" presents the evolution of the geographical area of the South Tyrol, from the pre

\section{HISTORY OF GEOGRAPHIC CONTRASTS RESEARCH AT NATIONAL LEVEL}

At the national level, there are regions that have undergone transformations similar to Bucovina, creating contrasts of the humanized space with the neighboring areas. There are similarities with other territories at national level regarding the parallel geodemographic and economic evolution in a historical period, which has left geographic imprints so far. Banat is a historical region that is economic elements. Conclusion indicates the amplitude of teritorial geographical contrasts.

demolition stage of the Austro-Hungarian Empire. The author analyzes the praised coexistence of today by discovering the elements of ethnic incompatibility. The social and economic divide is underlined by the segregation policies between Germans, Italians and Ladinos. Any action starts with the declaration of belonging to an ethnic group. [4]

The Transnistrian region of the Republic of Moldova was established as the territory of Moldova until 1924. From this period followed a succession of geodemographic transformations caused by changes of border and authority. Due to the ethnic heterogeneity with the Republic of Moldova and a sustainable economy created by the financing of the Soviet Union, it is individualized as a distinct region entering the geographical area of influence of the Russian Federation.

Vladimir Fomenko in the work „MoldovaTransnistria: aspecte sociale" , 2009, highlights the geodemographic consequences due to the conflict of the 1990s and on the other hand the creation of the Transnistrian ideology distinct from the Moldovian one. [5]

Valeriu Moşneaga „Populația Moldovei în contextul migratiilor moderne", 2009 compares the emigration directions of the population from the left and right of the Dniester. The result is predictably determined by Transdniestria's affinities with a massive migration to the Russian Federation. The preference of the Moldavians to the countries of western Europe and of the population from Transnistria to the Russian Federation is highlighted. The forced emigration caused by the conflicting pulsations during the 90s in the left and right of the Dniester resulted in a definite migration percentage. Immigration is a negligible element in terms of quantity. At the same time, there are divergent elections between the two regions regarding emigration options [6] .

currently fragmented, joining three states: Serbia, Hungary and Romania. The history of this territory is related to the alternation of the dominions of the Kingdom of Hungary, the Ottoman Empire and the Austro-Hungarian Empire. It constitutes a geodemographic and economic match with Bukovina by changing the ethnic composition and the succession of dominion over the territory. 
With an area of 18,966 km2, it is an ethnic mosaic consisting of: Germans, Serbs, Hungarians, Czechs, Slovaks, contributing to the diversification of activities and differentiation of the cultural landscape of the area. The territorial contrasts with the proximity of the region are evident due to the way of arranging the geographical space with central-European resonances.

The Romanian Banat is a relatively homogeneous region, after the last administrative-territorial organization, entering the composition of the counties: Timiș, Caraș-Severin, partially Arad and Mehedinți.

Oltenia or Wallachia Mică entered the Habsburg domination for a period of 20 years, being the region that rejected the West-European influence. The interest for research is directed to Mehedinți county, the territorial contrast being evident due to the imaginary border route within the administrative-territorial entity, of the two historical regions Banat and Oltenia, which have evolved differently, historicaly during certain periods.

The western extremity of the county of Mehedinți with an area of 750 squared kilometers formed by the settlements: Eibenthal, Dubova, Svinița and Orşova are part of the historical Banat.

Sebastian Ștefănucă in „Granița și grănicerii bănățeni- o abordare socio-istorică” 2010 addresses the imperial eastern border with Oltenia and the localities that hold the function of defense and transit. It analyzes the intensive colonization and the change of the humanized geographic landscape with the temporal evolution, including architectural elements. It is mentioned the organization of the rural area, the type of agriculture as differentiation of the morphology of the localities in comparison with Oltenia.

Rules of organization of the rural area are issued by the Austrian authorities with the help of a topographic engineer regarding the minimum width of the streets, the location of the churches, schools and commercial activities. The houses had to be set up with the street front with the complementary spaces located to the yard. [7]

The press article „Unde se termină Oltenia?, Orşova, ruptă de comunişti din regiunea Banatului, în urmă cu 47 de ani", Written by Alexandra Georgescu in 2015, highlights the injustices of the administrative-territorial delimitation of 1968, with the inclusion of some Banat territories in Mehedinți county. It specifies the unfair incorporation of an area distinct from the specific geodemographic and economic Oltenian. [8]

Maramures is a region located in the north of Romania, being in the vicinity of Bukovina, with an area of approximately 10000 square $\mathrm{km}$. Wood culture and monastic buildings of world importance create the elements of cultural relation. The name of "Maramureș Country" now symbolizes the distinction of this region with a particular specificity compared to Transylvania.

The county of Maramureş comprises the historical Maramureş ("the Land of Maramureş"), neighboring to the south by the "Countries" of Lapus, Chioar and Codr.

Between 1299-1538 and 1733-1918 Maramures was directly subordinated by Hungary, while the other three "countries" were continuously integrated only in Transylvania.

Between 1919-1925, the extra-Carpathian territories were integrated in the counties of Bistrița-Năsăud, Someș-Dăbâca and Satu Mare. Until 1968, the historical Maramures belonged to the counties: Baia Mare and Rodna.

After the last administrative-territorial organization, the "Transcarpathian" countries were included in a common administrative territory, having geographical elements that differentiate them due to the relative isolation of the settlements in the Maramures Depression and the distinct historical evolution.

This is one of the sources of geodemographic, economic and cultural contrasts visible today between the two parties. The population from the historical Maramures represents a homogenous traditionalist group, individualizing with its own architecture, gliding towards the east, and the other countries joined in the recent administrativeterritorial organization have geodemographic, economic and cultural similarities with Transylvania, resembling the countries of Silvania, Năsăud and Beiuș.

Many scientists include the historical Maramureş within the Carpathian area, bordered to the southwest by the volcanic mountains chain: Oas, Gutii and Țibleș. The most important researchers confirming this theory are: Vintilă Mihăilescu, Tiberiu Moraru and Simion Mehedinți.

Constantin Corniță in the „Țara Maramureșului, coordonate geografice și istorice" 2010, specifies the relative isolation of the territory due to the natural restrictive factor and the ethno-cultural evolution with visible differences from the other neighboring territories. He analyzes Maramures in its entirety including northern Ukraine. He cites from various geographers with an interest in researching the region and its limits: Emanuel de Martonne, Tiberiu Morariu, Ion Marin, Ion Conea, Vladimir Kubijovik. It studies the morphology of the settlements which is of the compact-assembled typology, the organization of the rural space and the communication routes with Moldova and Transylvania. [9]Tancred Brădățeanu in „Portul 
popular din regiunea Maramureş, zonele: Oaş, Maramureș, Lăpuș," 1964, delimits the two areas of Maramures county through differences but similarities. Lăpuşului country is closer

\section{HISTORY OF RESEARCH ON \\ GEOGRAPHICAL CONTRASTS IN SUCEAVA COUNTY}

The historical Bukovina is the territory annexed by the Habsburg Empire between 1775-1918. In some scientific treatises it bears the name of Bukovina from the South or The Southern Bukovina. In the demographically, economically and ethnographically to the Someșului valley and Năsăud Land. [10]. analysis of geographical contrasts, only the geographical space belonging to the current administrative-territorial area of Suceava county is taken into account.

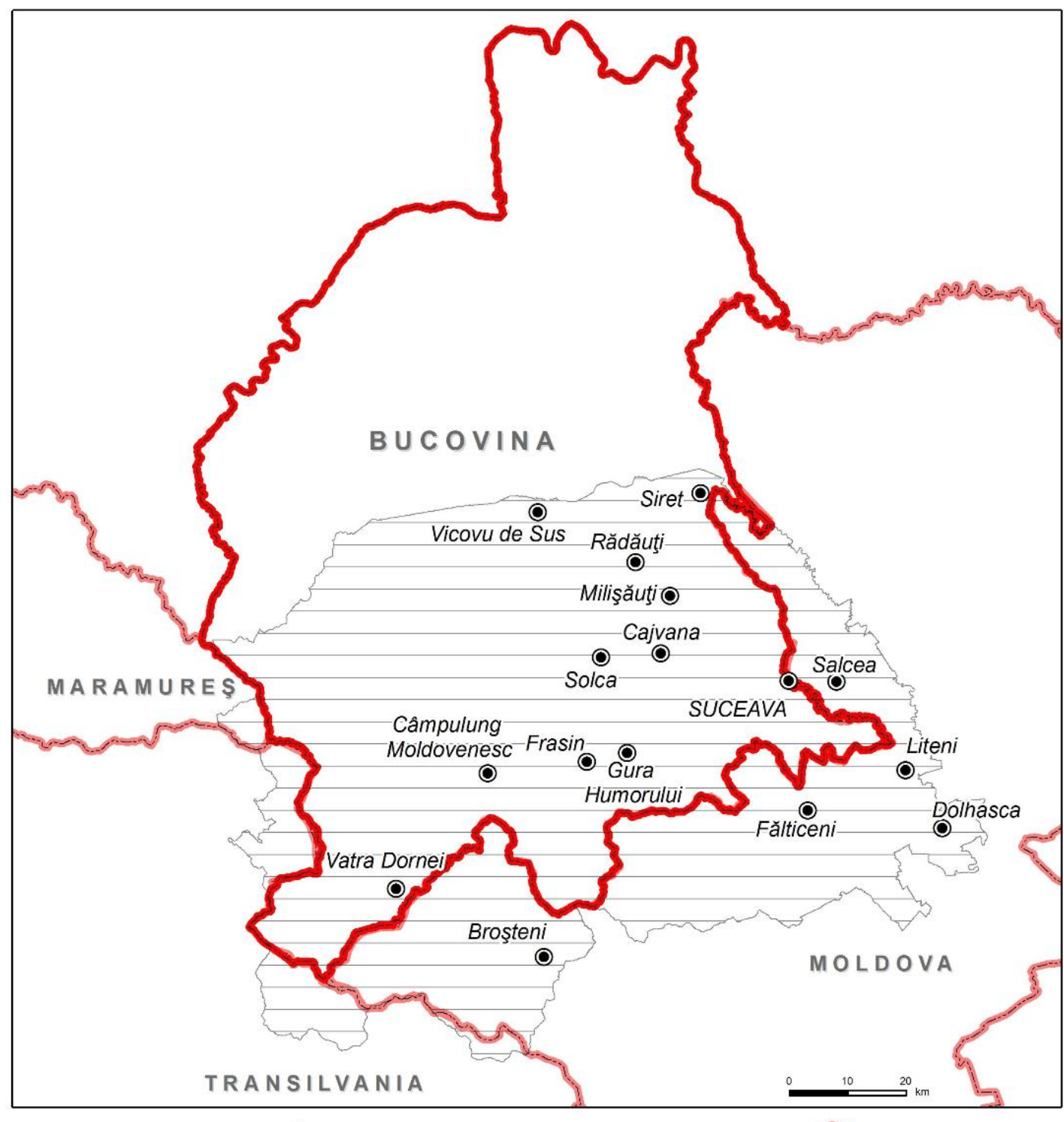

- Oraşe actuale Limita administrativă actuală a judeţului

Figure 1. The geographical boundaries of the historical Bukovina in Suceava county

The extrabucovinean territory overlaps with the evolution of Moldova after 1775, having common characteristics but with successions of administrative changes entering the counties: Suceava, Botoşani, Baia, Neamț. The two geographically homogeneous territories until 1775, belonging to the Upper Country of Moldova, started in a temporal development separated in terms of administration, the consequences being observed at the time of the 1918 union. The historical Bukovina being connected to the western civilization received the specific organization mode for an efficient administration. The qualitative and quantitative spatial data collected and systematized determined 
appropriate measures for the development of the territory. Infusions of populations with roles in various segments of the economy and relative political stability created the premises for a peaceful coexistence based on prosperity.

The extrabucovinean territory remained in the Eastern influence of the Ottoman Empire for a period, unorganized and without any development, without new economic branches.

After 1859 new opportunities and also positive geopolitical openings appear with the role of changing the humanized landscape. The cutting and then the spatial reassembly determined notable differences in the aspect of the ethnical, confessional structure, the degree of urbanization, the quality of the dwelling, the morphology of the localities, architecture, the way of capitalization of the resources.

In the case of the work "Geographic contrasts between the historical Bukovina and the extraBukovinean territory", there is no bibliographic information focused on geographical contrasts at the local level, the two spaces being investigated individually or together without identifying the geodemographic and economic differences. In the bibliographic analysis were identified those information that are of interest in the article. The most important bibliographic resources include three dimensions of the analysis of the geographical contrasts between the historical Bukovina and the extra-Bukovina territory in Suceava county.

\section{Territorial dimension:}

Alexandru Pînzar, with the article „Modernizarea administrației urbane a Sucevei la începutul perioadei imperiale", 2010, points to the factors of the appearance of the urban spaces in Bucovina and Moldova and quotas on the factors of economic and social development. The physiognomy of Suceava city is mentioned at the time of annexation, by means of the notes of General Spleny entitled "Description of the previous government". There are proposals for urban modernization that were implemented in the next period. [11]

Dimitrie Cantemir „Descrițio Moldaveae ”, makes an $\mathrm{x}$-ray of the spatiality in terms of the following components: geographical location, relief, climate, Moldovan waters, elements of vegetation, fauna and natural resources. In the analysis of the humanized territory, it specifies the organization of the space in the period before the occupation of Bukovina and Eastern Moldova in the Upper Country, Bessarabia and the Netherlands.

Ţara de Sus is made up of the following regions: Hotin, Dorohoi, Hârlău, Neamț, Bacău, Cernăuți and Suceava. The interest is directed to the lands that are currently identified with Suceava County.
It characterizes two important settlements illustrating the humanized geographical landscape: Suceava and Rădăuți. It describes the natural environment and humanized space of the former capital of Moldova, and confirms the existence of a settlement with 14,000 houses. Rădăuți Fair is only mentioned as an episcopal headquarters. [12]

\section{Geodemographic dynamics:}

Emil Ioan Emandi, , Bucovina şi spaţiul demografic românesc. Studiu demografic şi statistic" 1994, makes an incursion in the period preceding the imperial occupation 1772-1774, presenting the number of settlements including based on the data of colonel Romianțev. The data are compared with the first records made by the Habsburg authorities immediately after annexation of Bukovina. There is a comparison of the degree of urbanization in the temporal evolution with the other principalities. The numerical evolution of the population and human settlements between the years 1775-1940 unfolds. It studies the demographic evolution during the period of imperial occupation and after the reestablishment at the Romanian space.

It uses diagrams with numerical and percentage data to illustrate the decrease and then the growth of the Romanian ethnic population. It explains the role of immigration in the appearance and development of the localities. The territorial reunification from 1918 is accompanied by the geodemographic convergence with the Romanian space. The moment of leveling in the population dynamics with Moldova is highlighted, although there are differences regarding the mortality rate. [13]

Artur Gorovei., „,Folticenii-cercetări istorice asupra orașului", 1938, investigates the natural factors and the geopolitical context that favored the appearance of the fair then to the city of Falticeni. The argument of the loss of Bucovina and Suceava urban center determined the taking over of the administrative and then cultural functions, by a city located at the border. [14]

\section{The temporal evolution of geographical contrasts:}

Kurt Scharr in his book ,Die Landschaft Bukowina 1774-1918",, 2010 in the first chapters, cites the writer Karl Emil Franzos describing Bukovina as a front line between Byzantine and Latin Christianity, an island of the Orthodox West. The little-observed eastern imperial border in Europe becomes a model of ethnic coexistence and economic development over time.

It highlights the economic contrasts with the temporal evolution, but also the difficulties to block the crossing of the border especially of shepherds 
who found a favorable climate in Moldova. Analyzes the ethno-cultural convergence before 1918 of the Romanians in Bucovina with the territories moldovans in contrast to the aspirations of the ukrainian minority. [15]

\section{Economic contrasts:}

Ion Negură in the article: „Aspecte ale evoluției economice a Bucovinei sub stăpânirea Habsburgică", indicates the economic course during the imperial domination and the elements that laid the basis for a different development from Moldova, remaining in the oriental economic influence net.

It specifies the economic situation of the region at the time of annexation and the measures that created the premises of an upward economic dynamic: introduction of the land register, development of transport infrastructure, exploitation of natural resources (manganese, copper, lead, salt). It points out the differences in the level of income between the workers in different

\section{CONCLUSIONS AND DISCUSSIONS}

In conclusion, the research on the geographical contrasts is identified by analyzing some regions under the aspect of three coordinates framed by the determinant element "the territory":

- spatial element;

- demographic and social dimension;

- economic aspects;

The temporal changes of the regional map are the key to the emergence of the geodemographic and economic contrasts between the static region and the territorial cuts with ephemeral domination that have evolved differently over a historical period. The research focused on the analysis of the bibliography of the geographical contrasts in bucovina and the extra-bucovina territory and regions equivalent to Bucovina in the evolution of temporal geographical differences and then the convergence of the elements of the humanized space.

The term geographical contrast also appears in the form of synonyms such as:

- geographical heterogeneity,

- geographical differences,

- territorial divergences,

- territorial discontinuities,

- socio-economic cleavage,

- economic differences.

At present, there are major disagreements that include the following aspects: ethnic diversity in a relative equilibrium has created policies of areas of the empire, with a disadvantage for those in Bucovina. [16]

\section{Elements of ethnography}

Cazacu L, Chașovschi C., Enea V., Engel M. „Satul bucovinean, ca destinație turistică, cum îl protejăm și promovăm", delimits the particular characteristic of the Bucovina architecture through elements related to: the body of the house, the shape of the roof, the colors and materials used, the morphology the facades, the foundation of the house, the specificity of the fences and gates, the courtyard and the fountain.

It parallels the traditional architecture with recently appeared elements that do not respect the specificity of the area. The analyzed bibliography studies the geographical contrasts at global, national and local level with small elements of subjectivism of the authors, due to certain conjunctions determined by the historical period in which the territory was analyzed.

segregation in society (South Tyrol), frozen conflicts due to geopolitical influences (Transnistria).

Moderate territorial divergences, regarding the desire to return to a territorial entity defined historically (southwest of Mehedinti county). The outline of a particular geographical space of perceptions in which Bucovina as a territory eclipses the extra-bukovinian space of Suceava county.

Ioan Aurel Pop in the lecture dedicated to the 100th anniversary of the unification of Bukovina with Romania stated some arguments in support of the differentiations between Bukovina and the extraBukovinian territories in Moldova. He presented an example of socio-economic changes caused by the western connection in Bukovina as early as the 18th century. It asserts its belonging to a geographical sphere of advanced influence at the expense of a retrograde domination, even though the desire for self-determination is the fundamental element.

Bukovina, a name adopted during the imperial period, is unequivocally a territory belonging to the civilization of Moldova.

In the 144 years, which changed the political map of Moldova, they determined changes in the demographic and economic characteristics but did not alter the geographical connection with Moldova. 


\section{REFERENCES}

[1] Paul Vidal de la Blace „La France de 1 ' Est” (Lorena-Alsacia) 1917, pp. 1-105, 205-213

[2] William Oualid „, L'évolution industrielle de l'Alsace-Lorraine et de la France de 1871 à 1914” pp. 278-307

[3] Jens Woelk „South Tyrol is (not) Italy: A Special Case in a (De)federalizing system” pp.126-137

[4] Kager Thomas „South Tyrol: Mitigated but not Resolved 1998” Online Journal of Peace and Conflict Resolution 1.3 -- South Tyrol

[5] Vladimir Fomenko, Moldova-Transnistria: aspecte sociale,Editura Cu drag Chişinău, 2009 pp. 18-35

[6] Valeriu Moşneaga, Populația Moldovei în contextul migrațiilor migrațiilor moderne, Materialele conferinței ştiinţifice internaţionale, Chişinău, 9-10 noiembrie 2005 / UNESCO, USM, "Dialog Intercultural", "CAPTES". Vol. I. - Iaşi, 2006, $300 \mathrm{p}$

[7] Sebastian Ștefănucă , Granița și grănicerii bănățeni- o abordare socio-istorică, 2010

[8] Alexandra Georgescu ,Unde se termină Oltenia?, Orşova, ruptă de comunişti din regiunea Banatului, în urmă cu 47 de ani. Articol Adevărul 5 martie 2015.

[9] Constantin Corniță, Țara Maramureșului, coordonate geografice și istorice, 2010, Buletin științific, Fascicula Filologie, seria A, Vol. XIX, 2010

[10] Tancred Brădățeanu, Portul popular din regiunea Maramureș: zonele Oaș, Maramureș, Lăpuş, Sfatul Popular din regiunea Maramureș, Casa creației populare, 1964

[11] Alexandru Pînzar,Modernizarea administraţiei urbane a Sucevei la începutul perioadei imperiale 2010, Acta Moldaviae Septentrionalis, IX 2010, Muzeul Județean Botoșani

[12] Dimitrie Cantemir , Descrierea Moldovei, Cap. IV- Despre ținuturile și târgurile cele de acum ale Moldovei, 1716

[13] Emil Ioan Emandi, Louis Roman, Bucovina şi spaţiul demografic românesc. Studiu demografic şi statistic, Heralsius, IX 1994, Muzeul Județean Botoşani

[14] Artur Gorovei., „Folticenii-cercetări istorice asupra orașului", 1938

[15] Kurt Scharr, Die Landschaft Bukowina, Das Werden einer Region an der Peripherie 1774-1918, Böhlau Verlag Ges.m.b.H, 2010, pp.31-124

[16] Ion Negură, Aspecte ale evoluției economice a Bucovinei sub stăpânirea Habsburgică

[17] Cazacu L, Chașovschi C., Enea V., Engel M. ,Satul bucovinean, ca destinație turistică, cum îl protejăm și promovăm, Muzeul Bucovinei, Asociaţia de Dezvoltare Economică şi Regională, Universitatea Ştefan cel Mare, Ordinul Arhitecţilor şi Asociaţia pentru Turism Bucovina. 2014 